\title{
Probiotics and antibiotics as additives for sows and piglets during nursery phase
}

\author{
Marcus Leonardo Figueiredo Silva ${ }^{1}$, José Augusto de Freitas Lima ${ }^{1}$, Vinícius de Souza \\ Cantarellii $^{1}$, Níkolas de Oliveira Amaral ${ }^{1}$, Márcio Gilberto Zangerônimo ${ }^{2}$, Elias Tadeu Fialho ${ }^{1}$ \\ 1 Departamento de Zootecnia - UFLA. \\ 2 Departamento de Ciências Agrárias da UNIFENAS.
}

ABSTRACT - The purpose of this study was to evaluate the effects of the use of probiotics in diets for sows and piglets on performance and morphophysiologic parameters and the incidence of diarrhea in piglets during 28 days after weaning. A total of 120 pigs weaned at 21 days of age from 24 litters whose sows (primiparous) received probiotics or antibiotics from the $94^{\text {th }}$ day of gestation until weaning. It was used a complete randomized design in a $2 \times 3$ factorial (probiotics or antibiotics for sows and three diets for piglets - antibiotics, probiotics or probiotic-antibiotic combination) with four replicates of five animals to evaluate the performance and incidence of diarrhea. At 28 days of experiment, two animals from each plot were sacrificed for histological parameter measurement of the $\mathrm{pH}$ of the stomach, jejunum and cecum. The association antibiotics + probiotics in the diet of pigs resulted in greater weight gain and feed intake in animals born from of sows which received probiotics during the gestation and lactation phases. When females received antibiotics, the piglets receiving only probiotics showed higher consumption, but there were no differences for feed conversion. The use of antibiotics + probiotics in diets for piglets reduced the $\mathrm{pH}$ of the cecum and, when associated with the use of probiotics for sows, villous:crypt ratio in the jejunum increased. The use of growth promoters did not affect stomach $\mathrm{pH}$ neither the incidence of diarrhea. Supply of probiotics in the diet of sows during the gestation and lactation phases associated to the use in the diet of piglets after weaning is effective in maintaining animal performance, to histophysiological conditions in the gastrointestinal tract and control of diarrhea during the nursery phase.

Key Words: diarrhea, early stage, nutrition, performance, weaning

\section{Probióticos e antibióticos como aditivos para matrizes e leitões na fase de creche}

RESUMO - O objetivo neste trabalho foi avaliar os efeitos do uso de probióticos em dietas para matrizes e leitões, sobre o desempenho, os parâmetros morfofisiológicos e a indicência de diarréia nos leitões durante 28 dias após o desmame. Foram utilizados 120 leitões desmamados aos 21 dias, provenientes de 24 leitegadas cujas matrizes (primíparas) receberam probióticos ou antibióticos a partir do 940 dia de gestação até o desmame. Foi utilizado um delineamento inteiramente casualizado em esquema fatorial $2 \times 3$ (probióticos ou antibióticos para matrizes e três dietas para leitões - antibióticos, probióticos ou associação antibiótico-probiótico) com quatro repetições de cinco animais para avaliação do desempenho e da incidência de diarreia. Aos 28 dias de experimento, dois animais de cada parcela foram sacrificados para mensuração de parâmetros histológicos do jejuno e pH do estômago e ceco. A associação probióticos + antibióticos na dieta dos leitões resultou em maior ganho de peso e consumo de ração nos animais filhos das matrizes que receberam probióticos durante as fases de gestação e lactação. Quando as fêmeas receberam antibióticos, os leitões que receberam apenas probióticos apresentaram maior consumo, porém não foram observadas diferenças na conversão alimentar. O uso de antibióticos + probióticos na dieta de leitões reduziu o $\mathrm{pH}$ do ceco e, quando associado ao uso de probióticos para matrizes, aumentou a relação vilosidade:cripta do jejuno. O uso de promotores de crescimento não influenciou o pH estomacal nem a incidência de diarreia. O fornecimento de probióticos na dieta das matrizes durante as fases de gestação e lactação em assossiação ao uso na dieta dos leitões após o desmame é eficaz em manter o desempenho dos animais, às condições histofisiológicas do trato gastrintestinal e o controle de diarreia durante a fase de creche.

Palavras-chave: desempenho, desmame, diarréia, fase inicial, nutrição 


\section{Introduction}

It is a general consensus that daily weight gain in the first week after weaning has an enormous impact on subsequent performance. Specific dietary additives are incorporated at this stage in order to improve performance and benefit the health of animals. In addition to antibiotics other additives have been also used as prebiotics, probiotics and corresponding combinations (synbiotics), and acidifying (Tokach et al., 1992) for decades.

At weaning, the pig is challenged in terms of nutritional, thermal, and emotional health, a fact that affects the behavior and the hormonal balance of the animals (Orgeur et al., 2002). Regarding to nutrition, milk is completely replaced by a diet usually dry and less digestible. With the loss of lactogenic immunity, transfer to a new housing and in many cases, the rearrangement of litters, the consumption of food becomes low and variable, contributing to the increased incidence of diarrhea. At the same time, there is an occurrence of atrophy and loss of villus in the small intestine due to colonization of pathogenic bacteria, leading to losses in digestion and absorption of nutrients. In many cases, it is necessary a period from 10 to 14 days for animal to recover the level of energy consumption as in the days prior to weaning.

In this context, the use of antibiotics as growth promoters has reduced the negative effects of early weaning (Budiño et al., 2005). However, the idea of abolishing the use of these substances with these purposes has forced the use of alternative substances, such as probiotics, which have also shown the ability to improve the performance of weanling pigs (Estienne et al., 2005), but not always with satisfactory results.

The idea that the pigs should be ready for weaning during lactation is solid among pig farmers. We also know that the health of pigs is directly related to the health of its mother, since the first bacteria that colonize the gastrointestinal tract of piglets are from the environment.

Furthermore, the prevention of diarrheal diseases, the concept of administration of live microorganisms that act by antagonizing pathogenic bacteria appears to be effective. The exact fashion in how this antagonism is manifested is not completely understood and it may occur through production of inhibitory compounds such as lactic acid or by competition for nutrients and adhesion sites (Alexopoulos et al., 2001). However, contrasting results illustrate the complexity of interactions between dietary components, the microbiota (and metabolites), the enterocytes and the local immune system (Lallès et al., 2007).
In this sense, the present study was conducted to evaluate the use of probiotics in the diets of mothers and piglets on performance, morphological and physiological parameters and incidence of diarrhea for 28 days after weaning.

\section{Material and Methods}

The experiment was conducted in the Departamento de Zootecnia at Universidade Federal de Lavras, Lavras, in southern Minas Gerais.

The beginning of the experiment used 24 gilts at $94 \pm 2.3$ days of gestation, housed in individual cages during gestation, where they remained until the 107th day of gestation. In this group, 12 received standard diet (control) and antibiotic (amoxicillin 50\%, $400 \mathrm{~g}$ per tonne) and 12 received a diet containing probiotic (250 ppm - Table 1) instead of antibiotics, all at the daily quantity of 2.5 kilograms. After lactation, the animals began to receive rations of milk, also made for both groups.

During lactation, the litters of each group were distributed according to the diets of the sows in three groups: one group received antibiotics added to the diet (amoxicillin and colistin at 50\% in 400 and 240 per ton, respectively), the other orally received probiotics at 1,3,12 and 21 days of age and added to the diet at the beginning of the treatment $(1,000 \mathrm{ppm})$, and the third group received probiotics, also orally, on the same days and added to the $\operatorname{diet}(1,000 \mathrm{ppm})$ associated to the antibiotics. At the end of lactation, all piglets were weighed and transferred to the nursery.

In the nursery, 120 pigs originating from 24 litters were homogenized within each group of experimental diets, at initial weight of $6.19+0.72 \mathrm{~kg}$. The animals were kept in groups of five in pens containing automatic feeder and pacifier type drinker and they were weighed at the beginning, at 14 and 28 days of nursery. The supplied rations followed the same protocol stipulated for lactating: antibiotic, probiotic and antibiotic-probiotic, at the sameconcentrations.

Table 1 - Microbial composition of probiotic added to the diets of sows in gestation and lactation and to the diet of piglets on suckling period

\begin{tabular}{lr}
\hline Microorganim specie & Concentration $(\mathrm{cfu} / \mathrm{g})$ \\
\hline Bifidobacterium bifidum & $3.33 \times 10^{6}$ \\
Enterococcus faecium & $1.66 \times 10^{6}$ \\
Lactobacillus acidophilus & $3.33 \times 10^{6}$ \\
Lactobacillus plantarum & $1.66 \times 10^{5}$ \\
\hline Source: Levels of product warranty. &
\end{tabular}


Table 3 - Piglets performance receiving additives in diet, from sows that were also treated with antibiotic or probiotic during gestation and lactation

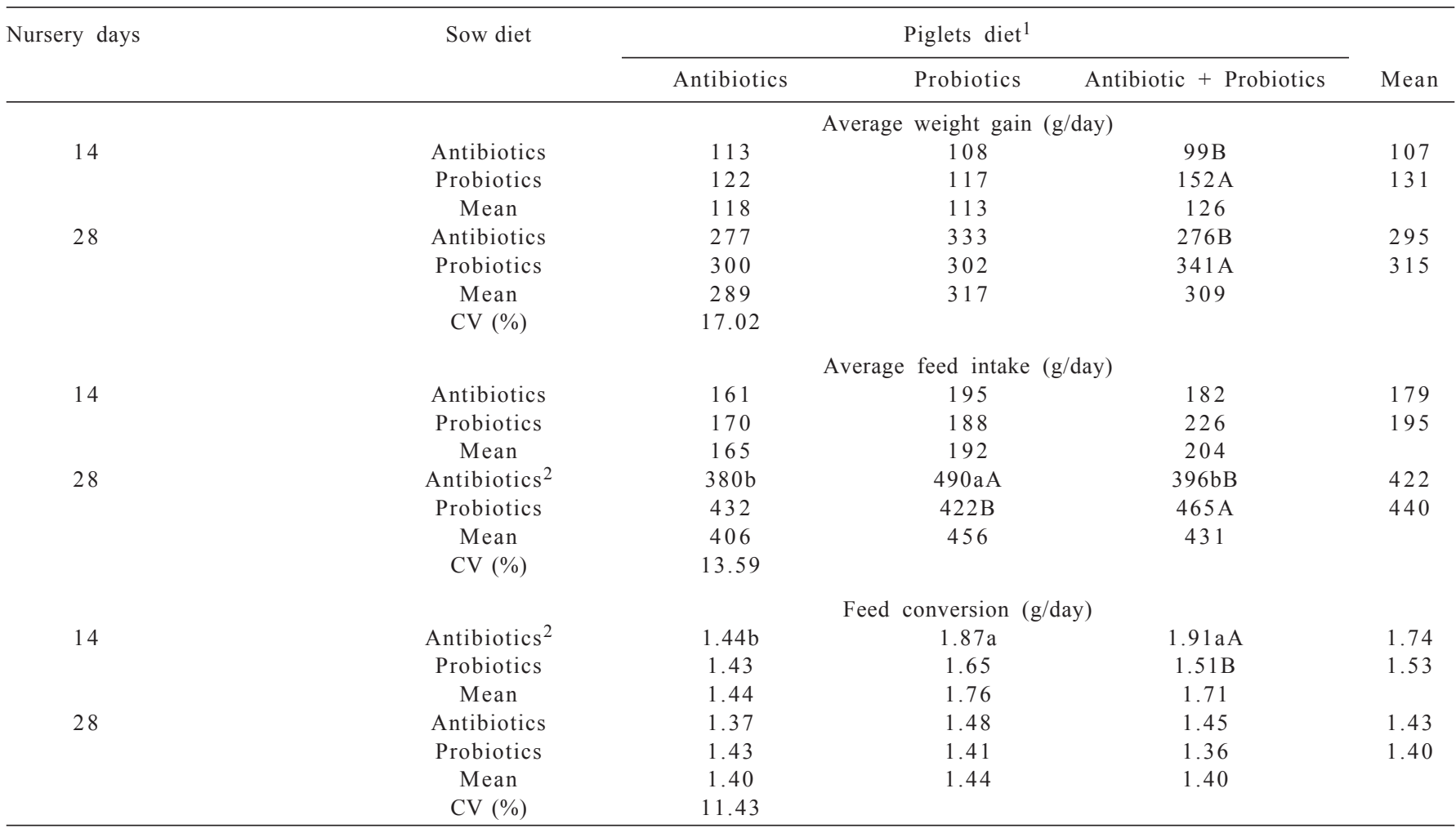

${ }_{1}^{1}$ Means followed by different uppercase letters in the column, within each time, differ $(\mathrm{P}<0.05)$ by $\mathrm{F}$ test.

2 Means followed by different lowercase letters in the row differ $(\mathrm{P}<0.05)$ by SNK test.

$\mathrm{CV}$ - coefficient of variation.

Concerning daily feed intake by pigs (Table 3 ), there were differences $(\mathrm{P}<0.05)$ only on 28 days of nursery. Piglets from mothers which received antibiotics in the diet of gestation/lactation fed diets containing only probiotics showed higher consumption compared to those from sows that received probiotics. However, these results were contrary to piglets fed antibiotic-probiotic combination in the diet.

Moreover, considering all the piglets from mothers which received antibiotics in the diets, consumption by animals that received probiotic only in the initial phase was higher $(\mathrm{P}<0.05)$ when compared to the other. This same effect was not observed $(\mathrm{P}>0.05)$ when the animals were from mothers which received probiotics in the diets.

For feed conversion, there was interaction $(\mathrm{P}<0.05)$ between diet of the sows and diet of piglets (Table 3). At 14 days of nursery, it was observed that the piglets from mothers which received antibiotics during late gestation and lactation, use of antibiotics in the starter diet promoted $(\mathrm{P}<0.05)$ better result than the diets containing probiotics, while this effect was not observed $(\mathrm{P}>0.05)$ in animals from mothers that received antibiotics. Comparing the combination antibiotic-probiotic for piglets, it was better $(\mathrm{P}>0.05)$ in animals from mothers which received a probiotic, which was not observed when antibiotic and probiotic was used alone in the diets of piglets. There was no effect $(\mathrm{P}>0.05)$ of additives or matrix or size at 28 days of nursery.

Alexopoulos et al. $(2001,2004)$ observed increased weight gain up to 49 days of age in the group sow and piglets fed with probiotics. Similar results were obtained by Estienne et al. (2005), when the authors observed weight gain and satiety for weaning pigs after receiving probiotics and housed in a mixture of litters. However, Taras et al. (2006) found no effect of the probiotic on the performance of the animals after weaning. According to these studies, the variation in results obtained from the literature may be related to genetics, the strain used as probiotic and especially to environmental conditions. In the latter case, the health challenge that the animals are subjected may directly affect the effect of additives on the intestinal health of animals.

In this study, the use of Bifidobacterium bifidum, Enterococcus faecium, Lactobacillus acidophilus and Lactobacillus plantarum resulted in better performance after weaning when used in the diet of mothers during gestation/lactation and it can be used to replace antibiotics in initial and pre-starter diet of piglets. Moreover, the greatest weight gain of piglets fed antibiotic-probiotic, from breeders which received probiotics in the diet, suggests 
even greater benefits for the combined use of these additives in diets for mothers and piglets.

Taras et al. (2007) observed that supplementation of diets with Bacillus cereus var. toyoi did not increase weight gain but it improved feed conversion of piglets weaned at approximately around $8 \%$. Furthermore, using Enterococcus faecium did not result in significant effect on the overall performance of the animals in the same stage.

In relation to histological parameters of the jejunum (Table 4), it was shown that the use of antibiotics in diet for sows resulted $(\mathrm{P}<0.05)$ in maximal height of villus in piglets at 14 days after weaning ( 35 days of age). This does not necessarily result in better animal performance. There was interaction $(\mathrm{P}<0.05)$ for crypt depth and villous:crypt ratio. When probiotic was used in the diet of the mothers, the use of probiotics associated with antibiotics in the diets of pigs allowed $(\mathrm{P}<0.05)$ a lower depth of crypts and higher villus:crypt ratio. These same results were observed $(\mathrm{P}<0.05)$ when using antibiotics in the diet for piglets and sows.

These results are consistent with those obtained by Utiyama et al. (2006), who did not report the beneficial effects of probiotics to improve gut integrity in piglets but according to these authors, the greatest benefit would be exercised for villus by antibiotics reducing the microbial metabolism and the decrease of metabolites, which would be toxic to the intestinal epithelium. Moreover, Budiño et al. (2005) found no difference between antibiotics and probiotics for villus height in the jejunum of piglets at 14 days after weaning.

Lodemann et al. (2008) observed discrete effects of probiotics on the absorptive and secretory properties of the epithelium of the mucosa in the jejunum and intestinal transport. Only a small increase in the transport of
L-glutamine was observed in the group treated with probiotics.

It was not observed effects $(\mathrm{P}>0.05)$ for the use of additives in diets of mothers and piglets in the stomach $\mathrm{pH}$ of animals slaughtered 14 days after weaning (Table 5). However, the use of probiotics associated with antibiotics resulted in cecal $\mathrm{pH}$ lower than when antibiotics were used only in the diet of piglets. This low $\mathrm{pH}$ could be related to better intestinal health of animals, however, there were no correlation among these results with the performance of animals.

The fecal score of piglets until 28 days of nursery was not affected $(\mathrm{P}>0.05)$ by the use of different growth promoters or their combinations in the diet of piglets or sows(Table 6). According to Taras et al. (2006), while studies with pigs and poultry have shown that probiotics have a positive effect on the feces, many of them show only a slight improvement in weight gain and feed conversion. According to these authors, the challenge may not be high enough to show the benefit of the use of probiotics on this factor. In this case, the diarrhea would occur due to less pathogenic microorganisms that cause self-limiting infections.

Taras et al. (2007) found that probiotics led to a significant reduction in the incidence of diarrhea after weaning compared with the control group, regardless of the application form, the concentration in the diet and when you start treatment. These results indicate that probiotics may somehow contribute to the health of pigs, but if used as part of a broad concept by integrating management factors and other additives, as described above.

Scharek et al. (2007a, b) found that supplementation with probiotics in the diet of mothers and piglets

Table 4 - Features of the jejunum of piglets receiving additives in the diet, from sows which also received antibiotics or probiotics during gestation and lactation

\begin{tabular}{|c|c|c|c|c|c|}
\hline \multirow[t]{2}{*}{ Variable } & \multirow[b]{2}{*}{ Sows diet } & \multicolumn{3}{|c|}{ Piglet diet $^{1}$} & \multirow[b]{2}{*}{ Mean } \\
\hline & & Antibiotics & Probiotics & Antibiotic + Probiotics & \\
\hline \multirow[t]{4}{*}{ Villus height $(\mu \mathrm{m})^{*}$} & Antibiotics & 320.0 & 275.0 & 295.0 & $296.7 \mathrm{a}$ \\
\hline & Probiotics & 257.5 & 252.5 & 265.0 & $258.3 b$ \\
\hline & Mean & 288.8 & 263.8 & 280.0 & 277.5 \\
\hline & CV $(\%)$ & 6.79 & & & \\
\hline \multirow[t]{4}{*}{ Cript depth $(\mu \mathrm{m})^{*}$} & Antibiotics & $126.5 \mathrm{a}$ & 117.0 & 107.8 & 117.1 \\
\hline & Probiotics & $154.5 \mathrm{Bb}$ & $131.8 \mathrm{~B}$ & $88.0 \mathrm{~A}$ & 124.8 \\
\hline & Mean & 140.5 & 124.4 & 97.9 & 120.9 \\
\hline & CV $(\%)$ & 7.73 & & & \\
\hline \multirow[t]{4}{*}{ Relation villus:cript } & Antibiotics & $2.7 \mathrm{a}$ & 2.4 & 2.8 & 2.6 \\
\hline & Probiotics & $1.7 \mathrm{Bb}$ & $2.0 \mathrm{~B}$ & $3.3 \mathrm{~A}$ & 2.3 \\
\hline & Mean & 2.2 & 2.2 & 3.1 & 2.5 \\
\hline & CV $(\%)$ & 12.32 & & & \\
\hline
\end{tabular}

* Choice of transformation: square root. CV - coefficient of variation.

${ }^{1}$ Means followed by different uppercase letters in the row differ $(\mathrm{P}<0.05)$ by SNK test.

${ }^{2}$ Means followed by different lowercase letters in the column differ $(\mathrm{P}<0.05)$ by $\mathrm{F}$ test. 
Table 5 - Gastric and cecal $\mathrm{pH}$ of piglets receiving additives in the diet, from sows who received antibiotics or probiotics during gestation and lactation

\begin{tabular}{|c|c|c|c|c|c|}
\hline \multirow[t]{2}{*}{ Variable } & \multirow[t]{2}{*}{ Sow diet } & \multicolumn{3}{|c|}{ Piglets diet $^{1}$} & \multirow[b]{2}{*}{ Mean } \\
\hline & & Antibiotics & Probiotics & Antibiotic + Probiotics & \\
\hline \multirow[t]{4}{*}{ Gastric $\mathrm{pH}^{* 1}$} & Antibiotics & 4.63 & 4.37 & 5.13 & 4.71 \\
\hline & Probiotics & 4.93 & 4.74 & 3.97 & 4.55 \\
\hline & Mean & 4.78 & 4.56 & 4.55 & \\
\hline & CV (\%) & 9.01 & & & \\
\hline \multirow[t]{4}{*}{ Cecal pH *2 } & Antibiotics & 6.57 & 6.46 & 6.14 & 6.39 \\
\hline & Probiotics & 6.67 & 6.46 & 6.35 & 6.49 \\
\hline & Mean & $6.62 \mathrm{a}$ & $6.46 \mathrm{ab}$ & $6.25 b$ & \\
\hline & $\mathrm{CV}(\%)$ & 3.54 & & & \\
\hline
\end{tabular}

* Optional square root transformation. CV - coefficient of variation.

${ }^{1}$ Not significant $(\mathrm{P}>0.05)$.

2 Significant by SNK test $(\mathrm{P}<0.05)$

Table 6 - Fecal score of piglets receiving additives in the diet from sows who received antibiotics or probiotics during gestation and lactation ${ }^{1}$

\begin{tabular}{|c|c|c|c|c|c|}
\hline \multirow[b]{2}{*}{ Sow } & \multirow{2}{*}{$\begin{array}{c}\text { Diet } \\
\text { Piglet }\end{array}$} & \multicolumn{4}{|c|}{ Fecal score $(\%)$} \\
\hline & & 0 & 1 & 2 & 3 \\
\hline \multirow{2}{*}{ Antibiotics } & Antibiotics & 66.4 & 18.2 & 8.1 & 7.2 \\
\hline & Antibiotics + Probiotics & 62.8 & 25.4 & 8.2 & 3.6 \\
\hline \multirow[b]{2}{*}{ Probiotics } & Antibiotics & 65.0 & 21.1 & 9.6 & 4.3 \\
\hline & Probiotics & 59.8 & 20.7 & 10.7 & 8.7 \\
\hline
\end{tabular}

${ }^{1}$ Not significant at Chi-square $(\mathrm{P}>0.05)$ test.

demonstrated a positive effect on the intestinal immune system of piglets at weaning (28 days) and during the nursery phase. Moreover, the prevalence of Escherichia coli associated with pathogenic groups was lower with the use of probiotics, indicating better health status of pigs in this study.

In general, probiotics that contain different strains of bacteria appear to be effective since they increase the possibility of predominance of one or more strain in different situations (Walsh et al., 2008) and they may be used to reduce post-weaning diarrhea instead of antibiotics. However, other factors must also be considered for control of diarrhea after weaning, such as nutrition and environmental conditions to which animals are subjected.

\section{Conclusions}

The use of probiotics in the diet of sows in late gestation and during lactation, associated with the use of probiotics in the diet of piglets after weaning is effective in maintaining animal performance, the histo-physiological conditions of the gastrointestinal tract and the incidence of diarrhea during the nursery phase.

\section{Acknowledgement}

The authors gratefully thank FAPEMIG (Research Support Foundation of Minas Gerais) for their financial support for this project.

\section{References}

ALEXOPOULOS, C.; GEORGOULAKIS, I.E.; TZIVARA, A. et al. Field evaluation of the efficacy of a probiotic containing Bacillus licheniformis and Bacillus subtilis spores, on the health status and performance of sows and their litters. Journal of Animal Physiology and Animal Nutrition, v.88, p.381-392, 2004.

ALEXOPOULOS, C.; KARAGIANNIDIS, A.; KRITAS, S.K. et al. Field evaluation of a bioregulator containing live bacillus cereus spores on health status and performance of sows and their litters. Journal of Veterinary Medicine, v.48, n.3, p.137-145, 2001.

BUDIÑO, F.E.L.; THOMAZ, M.C.; KRONKA, R.N. et al. Effect of probiotic and prebiotic inclusion in weaned piglet diets on structure and ultra-structure of small intestine. Brazilian Archives of Biology and Technology, v.48, n.6, p.921-929, 2005 .

ESTIENNE, M.J.; HARTSOCK, T.; HARPER, A.F. Effects of antibiotics and probiotics on suckling pig and weaned pig performance. International Journal of Applied Research In Veterinary Medicine, v.3, n.4, p.303-308, 2005.

FERREIRA, D.F. Análises estatísticas por meio do Sisvar para Windows versão 4.0. In: REUNIÃO ANUAL DA REGIÃO 
BRASILEIRA DA SOCIEDADE INTERNACIONAL DE BIOMETRIA, 45., 2000, São Carlos. Anais... São Carlos: UFSCar, 2000. p.255-258.

JUNQUEIRA, L.C.U.; JUNQUEIRA, L.M.M.S. Técnicas básicas de citologia e histologia. São Paulo: UFP, 1983. 123p.

LAINE, T.M.; LYYTIKÄINEN, T.; YLIAHO, M. Risk factors for post-weaning diarrhoea on piglet producing farms inFinland. Acta Veterinaria Scandinavica, v.50, p.21, 2008.

LALLÈS, J.; BOSI, P.; HAUKE, S. et al. Weaning: a challenge to gut physiologists. Livestock Science, v.108, p.82-93, 2007.

LODEMANN, U.; LORENZ, B.M.; WEYRAUCH, K.D. et al. Effects of Bacillus cereus var. toyoi as probiotic feed supplement on intestinal transport and barrier function in piglets. Archives of Animal Nutrition, v.62, n.2, p.87-106, 2008.

ORGEUR, P.; LE DIVIDICH, J.; COLSON, V. et al. La relation mère-jeune chez les porcins: de la naissance au savrage. INRA Productions Animales, v.15, n.3, p.185-198, 2002.

ROSTAGNO, R.S.; ALBINO, L.F.T.; DONZELE, J.L. et al. Tabelas brasileiras para aves e suínos: composição de alimentos e exigências nutricionais. 2.ed. Viçosa, MG: UFV, 2005. 186p.

SCHAREK, L.; ALTHERR, B.J.; TÖLKE, C. et al. Influence of the probiotic Bacillus cereus var. toyoi on the intestinal immunity of piglets. Veterinary Immunology and Immunopathology, v.120, p.136-147, 2007a.

SCHAREK, L.; GUTH, J.; FILTER, M. et al. Impact of the probiotic bacteria Enterococcus faecium NCIMB 10415 (SF68) and
Bacillus cereus var. toyoi NCIMB 40112 on the development of serum IgG and fecal IgA of sows and their piglets. Archives of Animal Nutrition, v.61, n.4, p.223-234, 2007b.

TARAS, D.; VAHJEN, M.M.; SIMON, O. Performance, diarrhea incidence, and occurrence of Escherichia coli virulence genes during long-term administration of a probiotic Enterococcus faecium strain to sows and piglets. Journal of Animal Science, v. 84, p.608-617, 2006.

TARAS, D.; VAHJEN, M.M.; SIMON, O. Probiotics in pigs: modulation of their intestinal distribution and of their impact on health and performance. Livestock Science, n.108, p.229-223, 2007.

TOKACH, M.D.; GOODBAND, R.D.; NELSSEN, J.L. et al. Influence of weaning weight and growth during the first week post-weaning on subsequent pig performance. Swine Day: Kansas State University, 1992. p.15-17.

UTIYAMA, C.E.; OETTING, L.L.; GIANI, P.A. et al. Efeitos de antimicrobianos, prebióticos, probióticos e extratos vegetais sobre a microbiota intestinal, a freqüência de diarréia e o desempenho de leitões recém-desmamados. Revista Brasileira de Zootecnia, v.35, n.6, p.2359-2367, 2006.

WALSH, M.C.; GARDINER, G.E.; LAWLOR, P.G. et al. Predominance of a bacteriocin-producing Lactobacillus salivarus component of a five-strain probiotic in the porcine ileum and effects on host immune phenotype. FEMS Microbiology Ecology, v.64, n.2, p.317-327, 2008. 